\title{
REFLECTIONS ON THE AMERICAN MEDIA
}

The most talked-about subject in this study was the media. Some of it was unsolicited, but most was generated from the question 'What do you think of the American media?' The question evoked intense discussion and a lot of emotion. Many respondents said that the media in general portrayed Muslims negatively, while some mentioned a particular media outlet and provided anecdotes. In Chapter 3 I pointed out that most of the respondents claimed to have dual or multiple identities, but when they spoke about issues that were 'near and dear' to them, their ethnic or religious identities came to the fore. As I discussed in Chapter 1, emotion and identity are interrelated. Sometimes people create their ingroups by choice - they desire to stay with their own cultural group - and sometimes external factors, such as the media and mainstream politics, lead to the creation of ingroups. The creation of strong ingroups may lead to less interaction with the wider society, which slows progress towards social cohesion between the two groups.

Between 14 and 22 July 2011, the Pew Research Center in Washington, DC conducted telephone interviews with 1,033 Muslims (both male and female, aged eighteen and over). Among several questions (discussed in other chapters) they asked: 'Do you think that coverage of Islam and Muslims by American news organisations is generally fair or unfair?' About 55 per cent of respondents thought that the media coverage of Islam and Muslims by US news organisations was generally unfair. Back in 2007, when the same question was asked (to a different sample), about 57 per cent of American Muslims regarded the US media as 'unfair'. In 2011, 30 per cent observed that the news coverage was fair, while 25 per cent said it depended on the news or were unsure. ${ }^{1}$ Americanborn Muslims (about 63 per cent) were more likely than their overseas-born counterparts (50 per cent) to observe that the media coverage of Muslims was 'unfair'. ${ }^{2}$ 
The difference between the Pew Research Center's survey and my fieldwork is that, though the number of participants $(1,033)$ was much larger than the number in my study (379), their survey was conducted over the phone, so there was less opportunity for discussion. Most of my participants elaborated their views on the American media (see Table 4.1 below). Another difference is that the Pew Research Center included only adult participants (eighteen years and over), and they did not provide a breakdown of male and female participants. In my study the total number of participants was 379 (167 male, 212 female, mostly US born); and of these 188 , or almost exactly half, were young participants, aged fifteen to seventeen ( 74 male, 114 female), with the remainder being eighteen and over. Overall, the majority of participants (about 78 per cent) observed that the American media was unfair (further analysis of Table 4.1 follows later). Finally, the most important difference was that by the time I interviewed my participants a relationship had been formed; therefore, respondents may have been less guarded in their responses than in the Pew survey.

In this chapter I first discuss some academics' observations on the American media. Secondly, I report the patterns of my 379 participants' responses on the topic of the media (summarised in Table 4.1). Thirdly, I discuss the major pattern emerging from the participants' responses and examine some print media coverage ${ }^{3}$ of the Fort Hood shooting and some other subsequent incidents to assess whether the young Muslims' view that the media is 'biased' is justified. Fourthly, I examine the Christian-Muslim dichotomy in media reporting by discussing the Christian militia incident in Michigan. Finally, I examine participants' positive comments on the media.

\section{Academics' observations on the media}

In Covering Islam, Edward Said observed that there are many troubling incidents associated with the Muslim world, such as the killing of 240 American marines by a Muslim group in Lebanon in 1983, the Lockerbie bombing of Pan Am Flight 109 in 1988, and Ayatollah Khomeini's fatwa against Salman Rushdie in 1989; but when the western mass media applies a blanket label of 'Islam' to an event, either as an explanation or indiscriminately to condemn 'Islam', this is usually a form of attack against the Islamic world. ${ }^{4}$

Here is a sample of studies that have been published on the print media. In 1984 E. Ghareeb noted that some prestigious newspapers, such as the Washington Post, portrayed Muslims as terrorists. ${ }^{5}$ In 1999 Ahmadullah Siddiqi observed that over the past several years some newspapers and magazines had identified Islam as the most significant threat to the liberal democracies of the West. These included The Economist (1992), Time (1993), the New York Times (1993), US News \& World Report (1993) and the Chicago Tribune (1995). ${ }^{6}$ Siddiqi noted that the western media 'have always pointed 
out that "Muslim men" were implicated in the World Trade Center bombing, [but] never did the media say that the suspects in [the] Oklahoma City bombing were Christians'. Siddiqi stated that the media were responsible for the backlash towards Muslims after the bombing of the Murrah Federal Building in Oklahoma City on 19 April 1995. Immediately after the bomb blast, radio and television started reporting that people of Middle Eastern origin were the prime suspects. Many experts and Congressman David McCurdy appeared on the media speculating that the bombers were of Middle Eastern origin. ${ }^{7}$ But later the suspects arrested were found to be 'white, Christians from the Midwest, not from the Middle East' ${ }^{8}$

Jack Shaheen also observed that, although Timothy McVeigh was an Irish Catholic, no one mentioned his ethnic or religious background. The Oklahoma bombing was immediately related to Middle Eastern suspects in news broadcasts, even on moderate TV channels such as ABC and CBS. Before 9/11, when nineteen Arab Muslims killed about 3,000 Americans, Arabs and Muslims were already regarded as threatening people, but afterwards it was assumed that all 1.3 billion Muslims were the 'other'. 9

Saud Joseph, Benjamine D'Harlingue and Alvin Wong analysed the New York Times from 2000 to 2004, observing that even before the 9/11 Twin Towers attacks it represented both Arab Americans and Muslim Americans as the 'other'. It is interesting to note that Arab Americans were portrayed largely as Muslims, even though the overwhelming majority are Christians. This tendency to conflate both groups into one 'collective', essentialised identity continued after 9/11, when Sikhs were also included under the label 'Arab American'. ${ }^{10}$ For example, after 9/11 the New York Times reported the repercussions for Arabs, Muslims and Sikhs under the headline 'Attacks and harassment of Arab Americans increase'. ${ }^{11}$ It is difficult to say whether the conflation of American Muslims (and Sikhs) with Arab Americans was a result of cultural ignorance on the part of the media, or whether it was an institutional bias that all Arabs are the 'other' (a bias that has been fuelled by the Israeli-Palestinian conflict).

Immediately after the 9/11 tragedy, through its reporting, the New York Times questioned Muslim Americans' loyalty. For example, in his report 'In U.S., echoes of rift of Muslims and Jews', columnist Laurie Goodstein quoted a girl who commented:

'I'm Arabic and Palestinian and I have just one thing to say,' said Yasmeen Hindi, 19, a customer at Uptown Deli Grocery. 'I feel bad, but Americans have to understand something: If we're going to get killed, they're going to get killed back. Stop supporting the Israelis.' 12

By extracting this quotation, the reporter implied that some Muslims were outraged at US foreign policy towards its ally Israel (so the 9/11 terrorist act 
was tacitly justified). Goodstein thereby suggested it was reasonable to doubt whether Muslim Americans were loyal citizens. ${ }^{13}$

Jane Smith has observed that some mainstream Americans are concerned that an increase in Muslim migration may 'lead to the growth of radical cells or even to advocacy of shari'a law', and this fear has been induced by some media, such as radio talkback programmes, TV shows and videos. ${ }^{14}$ In 2005 about twenty-eight million copies of a documentary film, Obsession: Radical Islam's War against the West, were distributed free of charge on DVD. ${ }^{15}$ In the film Islam was equated with Nazism under the label of 'Islamofacism'. It ended with a map of the world capped with a swastika, followed by scenes of carnage caused by 'Islamic radicals' ${ }^{16}$ Such fear-mongering tactics, together with some of the most prominent American Christian evangelical leaders' portrayal of Prophet Muhammad (PBUH) as a terrorist and Islam as an evil religion in the media, have not been helpful. ${ }^{17}$

\section{Participants' opinions of the media}

\section{Analysis}

The first five rows of Table 4.1 show that a large number of participants (203) had negative perceptions of the American media. The next sixteen rows, 6 to 21, also reveal the negative perceptions of ninety-one participants of the US media, and some of them provided specific examples, such as the Fort Hood shooting. Rows 22 ('MSNBC') to 29 ('some good and some bad') provide a different picture. Here fifty-two participants offered a positive or somewhat positive view. Row 30 reveals that eight participants emphasised that if Muslims hope for a better society then they themselves also have a role to play in improving their image (discussed in the Conclusion). The last row shows that twenty-five participants had no comments on the media. Overall, out of 379 participants, 294 (77.5 per cent) had negative views on the American media. In the following section, I discuss some of the key responses of the participants.

\section{Participants' observations}

Most of the participants in this study were critical of the American media in general and of the Fox channel in particular. Some participants mentioned Fox 5 (Boston, New York and Washington, DC) while others mentioned Fox 2 (Detroit and Florida). Though the participants defined their identities differently, they were unanimous in their views on Fox. For example, Zeenat (female, 16, US born of Bangladeshi background, national identity: Bengali) had this to say:

What I was really shocked about was in Fox 5 News during the elections they were not afraid to say that they had a problem with Obama being Muslim or coming from 


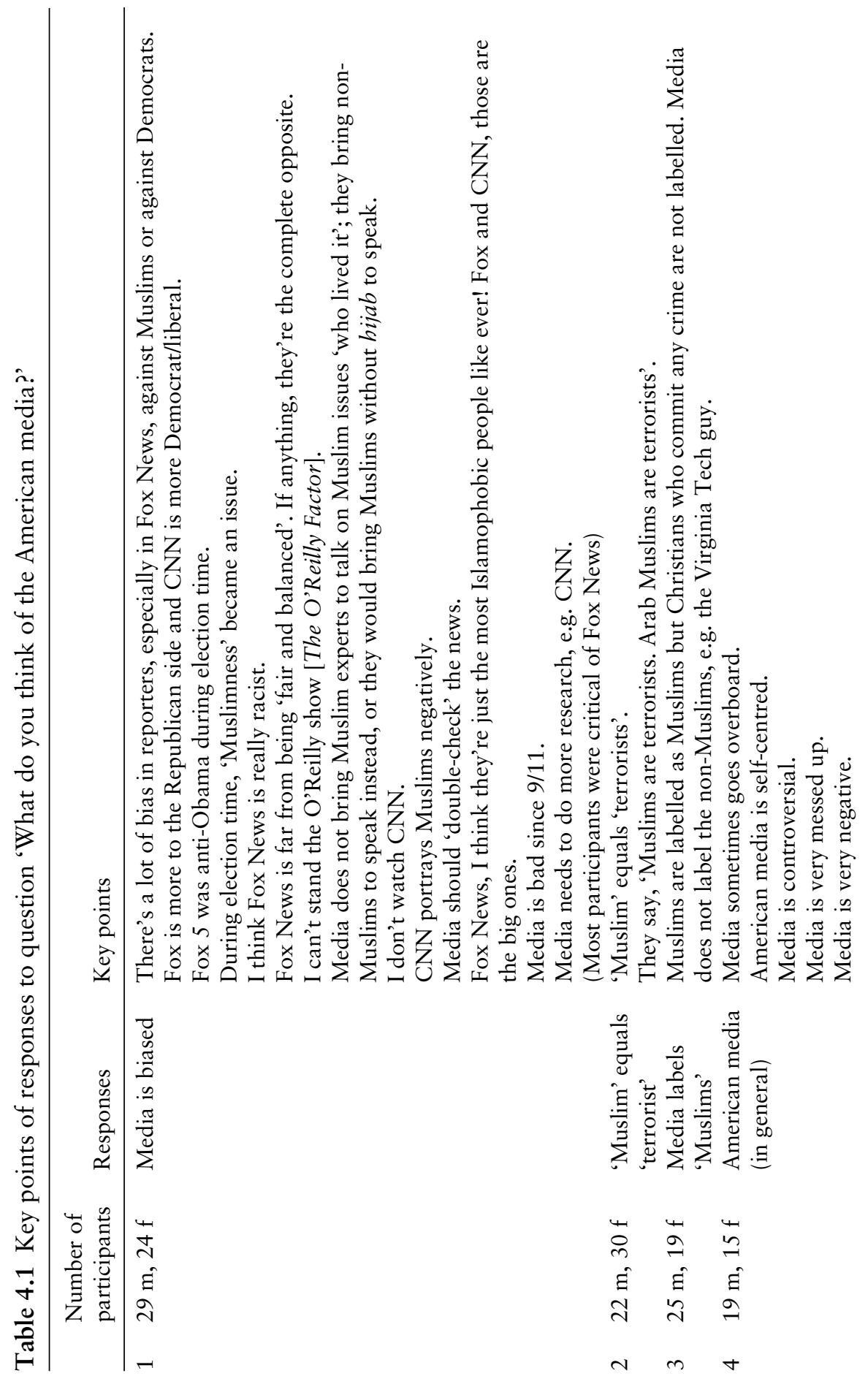




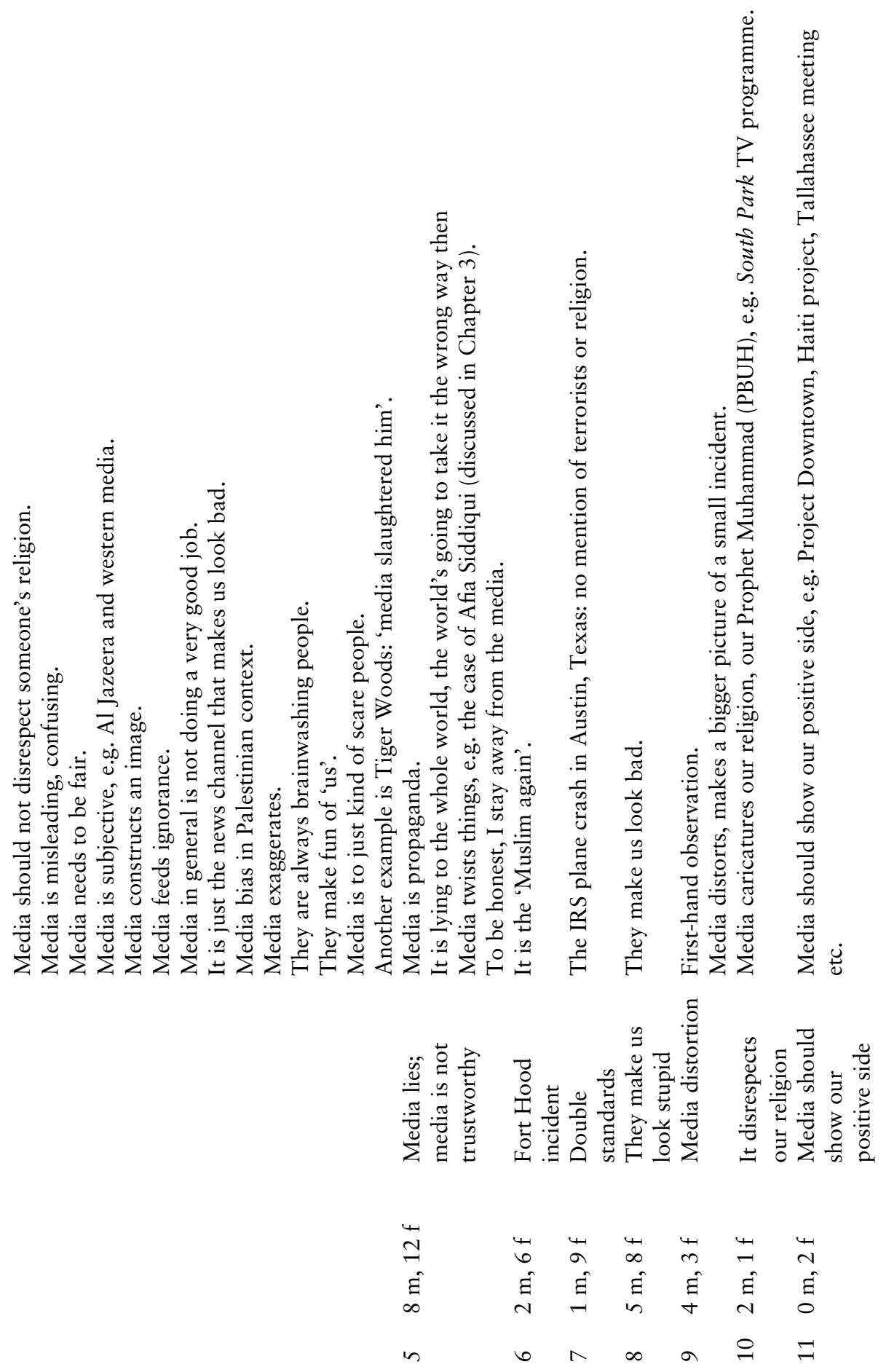




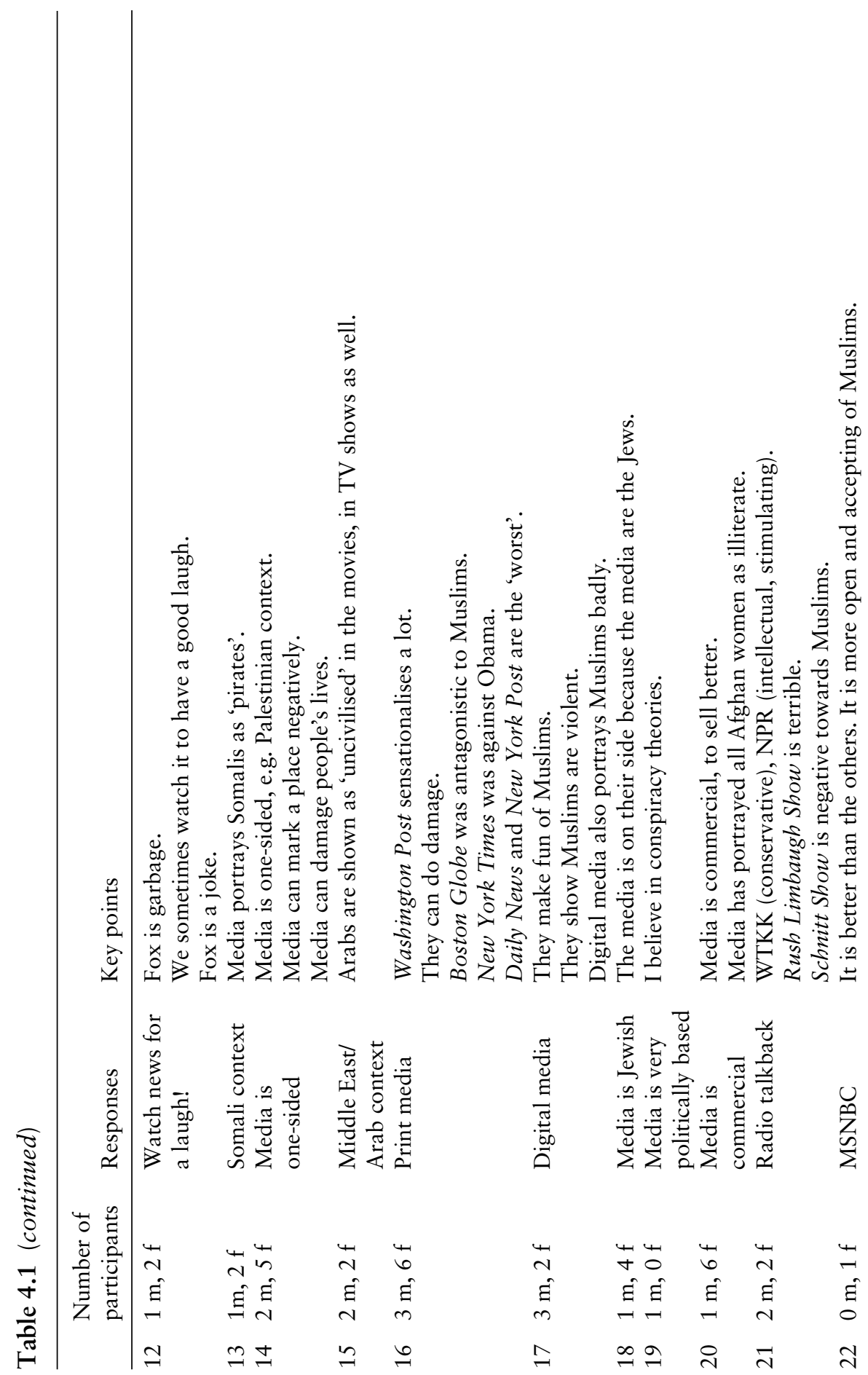




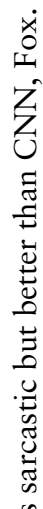

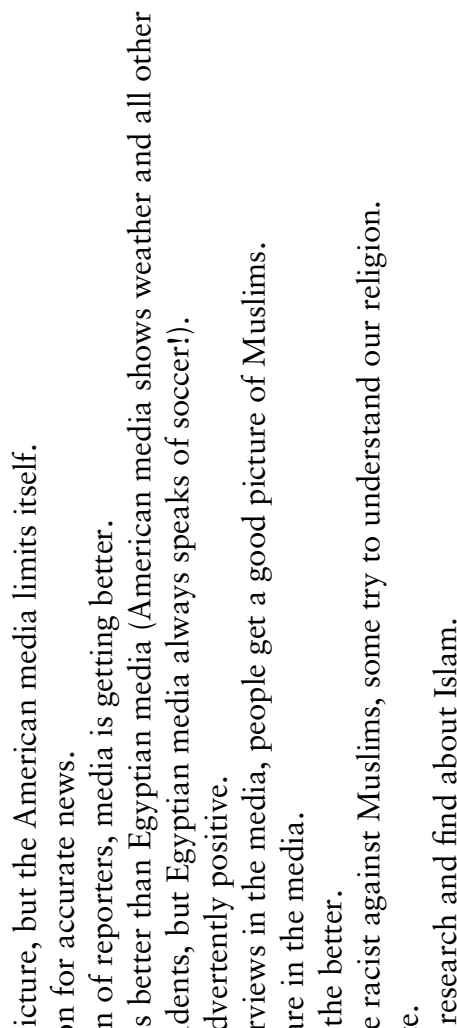

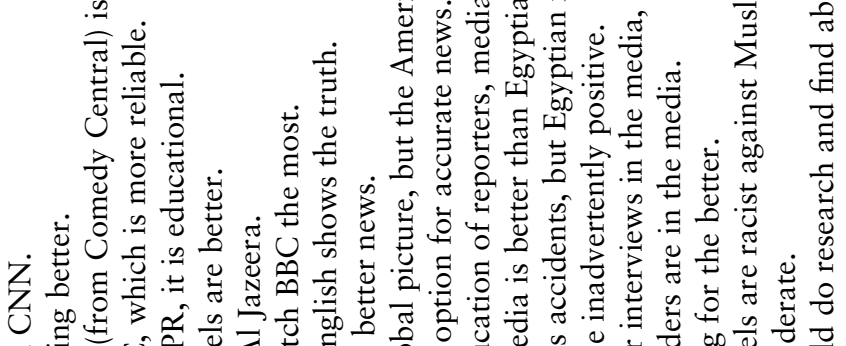

:

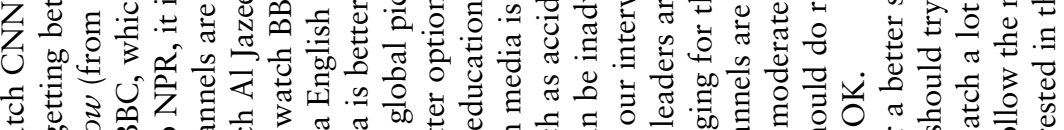

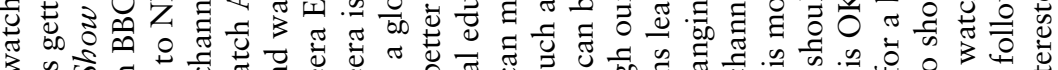

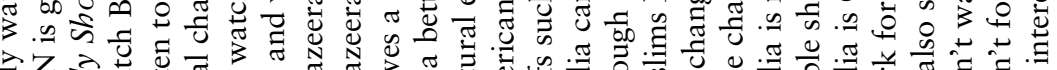

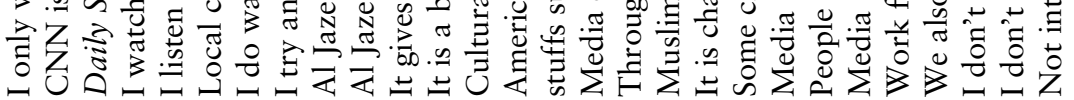

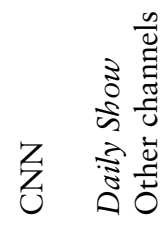
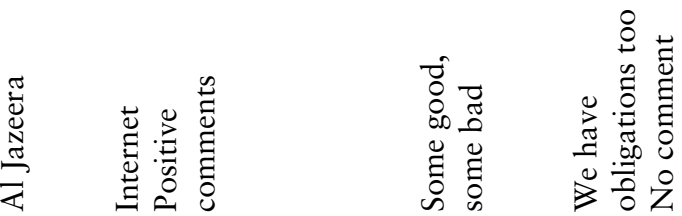

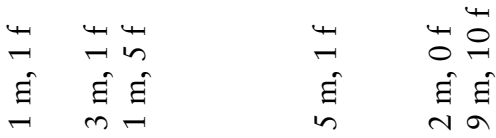

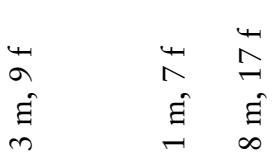

$\stackrel{4}{\pi}$

ปั

กิ

$\infty \pi$ 
Muslim roots. I feel like people don't care about if they're being racist . . . It's like an open thing that Muslims are hated and they're looked upon as terrorists. (Interview, New York, February 2010)

Doubts about whether Barack Obama was a Muslim were portrayed by other media as well, for example in the New York Times (discussed further in Chapter 6). The next participant, Fuad, of Egyptian background (male, 17, US born), said that he was a 'Muslim American Egyptian'. But he reflected his broader Arab identity when he said, 'If one Palestinian kills a Jewish person, they would say terrorist Palestinians kill Jews. If the Jewish army [sic] kills thousands of Palestinian women and children and men, they won't say the full story ... I think it was Fox' (interview, Florida, March 2010). Sohaib (25, overseas born of Pakistani background, national identity: several identities) spoke from his personal experience:

Fox News is notorious to take a very conservative approach. When I was president of a Muslim students' association [in a different state] ... the O'Reilly Factor show, they try to bring Muslim students on, but what they do is they always sort of back them into a corner and they're always asking them questions that will sort of lead them to say something that they want them to say. Something . . that they can pounce on. So the Fox News Channel is not a great channel when it comes to objective news ... Muslim issues, or issues pertaining to Muslims. (Interview, Massachusetts, November 2009)

For one participant, Aaqib (male, 22, overseas born of Bangladeshi background, national identity: Bangladeshi American), Fox News has become a laughing stock:

I do think the media sometimes tend to go overboard, they exaggerate a story and it just fuels the fire ... I wouldn't call them a news source; nowadays they're an entertainment source. Yeah so if I feel like laughing I'll turn to Fox and just have some fun. (Interview, New York, January 2010)

A Muslim leader, Yusef (male, 25, US born of Indian background, national identity: 'fifty-fifty'), spoke of his local newspaper from his firsthand experience.

I don't think [the] Miami Herald is really connected to Muslims or even when they are, they don't really cover the stories. For example, after the earthquake in Haiti, we did 'Support a Muslim Day for Haiti'. There was no coverage, or when there was coverage they did a piece [but] that's after I called and called and called and called and then finally they covered it but they didn't put [a] picture ... I mean, we had about forty or fifty young Muslims from different colleges and some high schools to come out and they volunteered ... The newspaper merely mentioned that Muslims were doing stuff. (Interview, Florida, March 2010) 
Anwar (male, 30, overseas born of Tunisian background, national identity: Muslim) said:

[The] majority of the media is fairly biased against Muslims. Various small outlets that are most of the time independent outlets are outlets that would give you a story that makes more sense to you as a Muslim. The rest are fairly biased because there is conglomerates now of media in the United States and these conglomerates are huge. Rupert Murdoch is one of the greatest examples. He is the owner of Fox and many other outlets ...

When the press, the TV, the radio is giving the same word, people are going to listen to it and it may be a fat lie but you repeat a fat lie three times or more and people start believing in it ... I think still there is somewhat of a much bigger negative view of Muslims because of this media. And to answer your question ['What do you think of the American media?'] simply, a majority of the media is against Muslims. (Interview, Florida, March 2010)

As noted in Table 4.1, the majority of the participants had negative views of the American media. When I was in the USA for this study, a few horrendous incidents occurred and I had a chance to make firsthand observations of how the media represented the news. The incidents were:

- the Fort Hood shooting incident, 5 November 2009

- the Times Square bombing attempt, 2 May 2010

- a pipe bomb blast on 10 May 2010

- the Arizona shooting incident, 8 January 2011

When my survey on the identity of young American Muslims commenced in late 2009, the shooting incident in Fort Hood, Texas had just taken place. While interviewing the participants on the media, discussion of the Fort Hood shootings arose. Most of the interviews were conducted by early May 2010, so the later topics (such as the Times Square bombing attempt) did not come up in the interviews. For the later topics, I resorted only to content/discourse analysis of the media. In the next section, I give a detailed discussion of the Fort Hood shooting incident and a brief discussion of the later events. The main focus of this examination was to check the validity of the participants' observation that the 'media is biased'.

\section{The Fort Hood shooting incident, 5 November 2009}

On 5 November 2009, Major Nidal Malik Hasan, a US Army psychiatrist, American born of Palestinian-Muslim background, aged thirty-nine, who had counselled soldiers involved in foreign wars, opened fire with two handguns on soldiers preparing for foreign deployment at the Fort Hood US Army post 
in Texas, killing thirteen and wounding thirty others. Responding to this shooting rampage, a civilian police officer shot and wounded Major Hasan. Hasan's cousin said that Hasan had been ordered to serve a term in Iraq but had resisted such a deployment for some time. The interviewees in this study did not comment on whether Hasan was a good or bad person, but they noted the different agendas of the media when an incident that is related to Muslims is mentioned. For example, Ali (male, 17, US born of Egyptian background, national identity: Arab American) said: 'Yeah, Fort Hood, once the guy did it they blamed Islam automatically but if a Christian guy does it they blame him but not the religion, so that just gets me pissed off' (interview, New York, January 2010). Nadira (female, 17, of Bangladeshi background, national identity: Bangladeshi Muslim) said:

I notice on the TV, like a few days ago the guy, he shot down thirteen people at Fort Hood. What he did was very bad, I don't think it's right to kill people, but one of the news anchors said that it was the worst terrorist attack since 9/11 and I didn't agree with that. 'Cos a few years back in Virginia Tech ... this Asian man, he shot down all those people, that was a terrorist attack too, but nobody labelled it as a terrorist attack because it wasn't done by a Muslim. They think only Muslims do terrorist attacks and I don't believe that - everybody from different cultures does that. (Interview, New York, January 2010)

The two respondents made observations on the media reports: Ali spoke of how Islam was emphasised after the Fort Hood incident, while Nadira recalled the Virginia Tech massacre, when a non-Muslim student, Seung-Hui Cho, killed thirty-two people and injured many others on the campus of Virginia Polytechnic Institute and State University in Blacksburg, Virginia before committing suicide on 16 April 2007, but the media did not emphasise either his ethnicity or his religion.

Bearing the views of the interviewees about the Fort Hood shooting in mind, for a week (6-13 November 2009) I examined six newspapers - USA Today, the New York Times, the Boston Globe, the Boston Herald, the Daily News (New York) and the New York Post - and analysed them for discourse and content. I found they all reported that Nidal Hasan was a Muslim through headlines or news content. While reporting news on Hasan, nonetheless, some newspapers maintained some moderation. It should also be noted that the next day, on 6 November, a similar shooting took place in Orlando, Florida. An unemployed engineer, Jason Rodriguez, aged forty, opened fire in his old office, killing one person and injuring five. When asked 'Why did you do it?' Rodriguez replied, 'Because they left me to rot. ${ }^{18}$ In The New York Times report, Rodriguez was portrayed as an angry man, but his ethnicity and religion were not mentioned. Also, the media reporting (both print and electronic media) on Rodriguez did not continue for days, as in the Hasan case. Hasan's 
story remained a cover page story for almost a week. A participant in this study, Mujeeb (male, 16, US born of Palestinian background, national identity: Arab American), observed:

I think it's [the media] not in a good way, to be honest with you. I feel if a Muslim killed someone in America and a white guy killed somebody, the white guy will be one day on the news. The Muslim guy would be ten days on the news, and then they'll be more scared of him. They'll keep it always behind their head. American dude, two days in the hype and it's done ... Yeah, if someone [Muslim] does something we get blamed. They make it like all Muslims do that. And that's not true. (Interview, Michigan, April 2010)

In the following sections I discuss how some print media made the Fort Hood tragedy a Muslim issue.

\section{USA Today}

USA Today reported: 'Nader Hasan, who described himself to Fox News as a cousin, said [Nidal] Hasan is a Muslim who went into the military against his parents' wishes.' His cousin further said that Major Hasan was a 'good American' who did not support wars in Iraq and Afghanistan. ${ }^{19}$ It was emphasised even more in the next issue that the Fort Hood incident was a 'Muslim' issue, as the headline indicated: 'Top brass warn against anti-Muslim backlash'. ${ }^{20}$ It reported that President Obama immediately cautioned Americans (possibly the American media) against saying that religion played a role in the attack or that it was 'terrorism'. Similarly, Army Chief of Staff General George Casey and Homeland Security Secretary Janet Napolitano expressed the same view as the president that Major Hasan's shooting case should not be made a religious issue. General Casey commented, 'Speculation could potentially heighten a backlash against some of our Muslim soldiers,' and Napolitano remarked, 'This was an individual who does not represent the Muslim faith.' The editorial of the same issue pointed out that warning signs were not detected when in 2007-8 Hasan justified suicide bombings at his lecture at the Maryland military medical college, and expressed his 'anti-American rants'. ${ }^{21}$

On 10 November 2009, in an article headed 'FBI: Fort Hood suspect had ties to radical imam', USA Today reported that Hasan exchanged emails with the terror suspect Anwar al-Awlaki.22 The headline 'radical imam' implied again that the Fort Hood shooting was a 'Muslim' issue. An opinion piece by Lucinda Roy, nevertheless, compared the atrocities committed by Seung-Hui Cho at Virginia Tech with those of Hasan since they were similar crimes but in different places. Roy wrote, 'Mass shootings often appear to be the result of personal alienation, anguish and rage, but they can also be intensely political 
acts. ${ }^{23}$ The next day in another opinion piece, James Alan Fox and Jack Levin discussed whether the shooting incidents that took place around the same time at Fort Hood and Orlando were workplace related and cautioned that Hasan's shooting incident should not be regarded as a terrorist act. ${ }^{24}$ In my examination of USA Today's reporting on Nidal Hasan, I found the opinion pieces of the columnists discussed above tried to present reasonable explanations, which is important for the readers' rational thinking. An interviewee in this study, Parveen (female, 15, of Bangladeshi background, national identity: 'American Bengali but my mom says that I have to be only Bengali'), observed:

I mean I don't blame American media for not understanding Muslims but I feel like they should at least take some time to see what's going on other than what, what's happened because ... people just don't do that, there has to be some psychological factor behind it for ... to cause someone to kill thirteen men just like that. (Interview, New York, January 2010)

Yet Major Hasan's religion really was a concern for some readers. For example, one person wrote to the editor:

He [Hasan] was suspected of Internet postings on suicide bombers. He said he was 'Muslim first and an American second' ... And the most disturbing supposed opinion of Hasan's was [that] the war in Iraq is 'a war against Islam' ... I am wondering whether he was left alone for fear of a racial profiling charge, or an antiMuslim complaint. ${ }^{25}$

\section{New York Times}

On its first day of reporting, the New York Times did not include the word 'Muslim' in its headline but its content created the reasonable suspicion that Major Hasan was a 'Muslim'. It reported:

In one posting on the Web site Scribd, a man named Nidal Hasan compared the heroism of a soldier who throws himself on a grenade to protect fellow soldiers to suicide bombers who sacrifice themselves to protect Muslims ... It could not be confirmed [by the FBI], however, that the writer was Major Hasan. ${ }^{26}$

The next day, the New York Times confirmed that the Fort Hood incident was a Muslim act. It reported that Hasan was 'an American-born Muslim of Palestinian descent, he was deeply dismayed by the wars in Iraq and Afghanistan but proud of his Army job. He wore Middle Eastern clothes to the convenience store and his battle fatigues to the mosque. ${ }^{27}$ Furthermore, 'he was trained to counsel troubled soldiers, but bottled up his own distress about deploying'. ${ }^{28}$ The article also reported that General 
George Casey had expressed concerns about a possible backlash against Muslims.

Over the next few days, the New York Times continued reporting on Major Hasan and in one instance he was pictured as a Muslim wearing Middle Eastern garments and a topi at the convenience store during the morning of his shooting rampage. ${ }^{29}$ Another report said:

Muslim leaders, advocates, and military service members have taken pains to denounce the shooting and distance themselves from Major Hasan. They make the point that his violence is no more representative of them than it is of other groups to which he belongs, including Army psychiatrists. ${ }^{30}$

The president of the Islamic Society of North America, Ingrid Mattson, commented, 'I don't understand why the Muslim-American community has to take responsibility for him ... The Army has had at least as much time and opportunity to form and shape this person as the Muslim community'. ${ }^{31}$

On 10 November 2009, the New York Times published five letters, one of which specifically labelled Islam as oppressive and murderous:

It is true that personal demons (delusion, rage and so on) are responsible for many of these incidents. It is also true that there are ideologies, including Communism, fascism, and yes, strains of Islam, that intellectually justify and even promote oppression and murder to achieve prescribed ends. ${ }^{32}$

The last item in this issue was an opinion by David Brooks, who was critical of the army's 'political correctness'. Brooks pointed out that on the fringes of the Muslim world some Muslims see 'a war between Islam on the one side and Christianity and Judaism on the other... They are the ones who go into the crowded rooms, shout "Allahu Akbar", or "God is great", and then start murdering. ${ }^{33}$ Brooks realised that for the moment 'political correctness' in the army was acceptable because otherwise Muslims might be singled out, but if this attitude continued then it would encourage self-radicalisation by 'individual[s] in the US as much as by groups in Tehran, Gaza or Kandahar'. ${ }^{34}$ The opinion piece obviously made the Fort Hood incident an Islamic issue, and suggested that both Israel and the USA were victims of 'Islamic terrorism'. On 12 November 2009, a Muslim wrote to the editor:

As a Muslim American, I am not afraid to raise my voice against terror perpetrated in the name of Islam. I do worry about the political correctness that might have prevented Major Hasan's superiors from putting him under some kind of supervision despite the danger signs. ${ }^{35}$ 


\section{Boston Globe}

The first-day reporting of the Boston Globe revealed that Major Hasan was a Muslim. It reported that Faizul Khan, a former imam at a mosque that Hasan attended, said that he often spoke with Hasan about how Hasan wanted to find a wife. ${ }^{36}$ It also reported that several years ago Hasan had been thinking of leaving the military 'after other soldiers harassed him for being a Muslim'. ${ }^{37}$ The next day the paper reported how Sergeant Kimberly Munley, a civilian police officer, raced towards the gunfire and fired at Hasan, bringing him down by shooting him four times. Some army officials reported that Hasan shouted 'Allahu Akbar!' (God is great) as he was shooting other officers. ${ }^{38}$ The photograph of Hasan in his Islamic garments (in the convenience store) was published in this issue. ${ }^{39}$

The Boston Sunday Globe finally labelled Hasan 'Muslim' in its headline. ${ }^{40}$ The new information in this report about Hasan was that he had once told his classmates that he was 'a Muslim first and an American second'. It also reported that the leader of the Islamic community in the region around Fort Hood, Osman Danquah, was concerned that Hasan did not integrate enough. Another headline, 'Fort Hood suspect reached out to radical imam', also profiled Hasan's religion. ${ }^{41}$ The report was similar to that of other newspapers of the day, mentioning Anwar al-Awlaki's praise in his blog for Hasan: 'He is a man of conscience who could not bear living the contradiction of being a Muslim and serving in an army that is fighting against his own people.' It also mentioned that Hasan's family attended the Dar al Hijrah Islamic centre in Falls Church, Virginia, where Awlaki was preaching in 2001, and that two of the 9/11 hijackers also attended Awlaki's mosque. In the opinion page, however, there were four letters of which two were on the topic of 'Muslims'. Both these letters included positive views on Muslims serving in the US military. ${ }^{42}$

\section{Boston Herald}

The Boston Herald's earlier issues had similar reports on Major Hasan. But on 9 November 2009, its headline 'Fort Hood suspect tied to 9/11 mosque' suggested that the Fort Hood incident was a Muslim concern. On 12 November 2009, the Herald reported:

Family members ... [suggested] that Hasan's anxiety as a Muslim over his pending deployment overseas might have been a factor in the deadly rampage.

Hasan had complained privately that he was harassed for his religion and wanted out of the Army. But there is no record of Hasan filing a harassment complaint or formally seeking release from the military, the officials said.

Doctors overseeing Hasan's training viewed him as belligerent, defensive and argumentative in his frequent discussions of his Muslim faith, a military official said. 
Hasan was characterized in meetings as a mediocre student and lazy worker. ${ }^{43}$

An interviewee in this study, Seerat (female, 17, US born of Palestinian background, national identity: Arab American), noted:

And just because he's a psychiatrist that kind of went off and shot people, they could have said 'A psychiatrist from this, this, this was involved in a shooting'. They didn't have to say 'a Muslim psychiatrist'. I think, okay, when you say Muslim, that makes it sound as if it's every Muslim. You can't judge an entire category based on one person. It's not fair, and I don't find it fair. When there's rapists and murderers, you don't say a Christian or a Catholic or Jewish. You don't see that right before their name. No, they only do it for Muslims, or that's what I've noticed. And that's not right at all. (Interview, Florida, March 2010)

Thus Seerat observed the general media profiling of Muslims and, in particular, that the Boston Herald had gone further by characterising a Muslim as a 'mediocre student and lazy'.

\section{Daily News}

The first page of the Daily News had a big headline 'Face to face with evil'. ${ }^{44}$ It was accompanied by a photograph of Nidal Malik Hasan. Another headline at the bottom of pp. 6-7 read 'Hasan went to same mosque as 9/11 thugs', followed by a similar story, reported in other newspapers, suggesting that Hasan may have been connected to the $9 / 11$ terrorists. The next day the editorial in the Daily News, entitled 'Fanaticism hits home', commented:

It was increasingly apparent that the mass murder at Fort Hood by Maj. Nidal Malik Hasan is the latest in a line of attacks or attempted attacks by Americans radicalized by fanatical Muslim ideology ... That Hasan began his rampage ... by saying 'Allabu Akbar' or 'God is Great' is relevant to his crime ... Hasan is the latest dot to connect in a picture of home grown radicalization. Another dot is Najibullah Zazi, the Denver man indicted here in an alleged bomb plot. Another dot is Tarek Mehanna, the Boston area man charged in a plot to kill, kidnap or maim people, including shoppers in U.S. malls. Another dot is Michael Finton, the 29-year-old convert to Islam arrested in an alleged plot to blow up a federal building in Illinois. Another dot is Hosam Maher Husein Smadi, the 19-year-old Jordanian arrested for hatching a similar plot against a Dallas skyscraper. Of late, there have been many such dots, and the U.S. ignores them at its peril. Perhaps the government did so in Hasan's case. ${ }^{45}$

The editorial was critical of the intelligence authorities for not detecting that Hasan was inclined to violence, even though he had exchanged emails with 
Anwar al-Awlaki. The editorial was also critical of the CAIR spokesperson Ibrahim Hooper, who said:

He could have just snapped from some kind of stress. The thing is, when these things happen and the guy's name is John Smith, nobody says, well, what about his religious beliefs? But when it is a Muslim-sounding name, that automatically comes into it.

The editorial reiterated that Hasan was 'swept along by the perversion of Islam - repeat, perversion - that has justified violence'. ${ }^{46}$ Later, in a Daily News opinion column, Charles Krauthammer was critical of some media sources who did not label Hasan's case as connected with Islam:

'I cringe that he's a Muslim . . I I think he's probably just a nut case,' said Newsweek's Evan Thomas. Some were more adamant. Time's Joe Klein decried 'odious attempts by Jewish extremists ... to argue that the massacre perpetrated by Nidal Hasan was somehow a direct consequence of his Islamic beliefs' ${ }^{47}$

\section{New York Post}

The cover page headline of the New York Post on 9 November was 'Fort Hood massacre, mosque of evil, killer's 9/11 terror link'. ${ }^{48}$ Although there was another headline relating to sport on top of the Fort Hood massacre, the words 'MOSQUE OF EVIL' were printed in such a big bold font that they dominated the news of the day. The paper reported, 'Fort Hood fiend Dr. Nidal Malik Hasan attended a Virginia mosque at the same time as two 9/11 hijackers - and authorities are now probing a possible link between the men, a source confirmed yesterday.' Another headline on page 5 read 'Killer prayed at mosque with hijackers'. It included similar information as the Boston Globe that Hasan had attended a Virginian mosque at the same time as the two 9/11 hijackers and that the mosque imam may have had ties with Anwar al-Awlaki. The overall presentation of the newspaper (with the headlines and photos) connected Islam with terrorism.

The next day, there was a large image (covering almost half the page) of Hasan in his Islamic attire and topi coming out of the convenience store. ${ }^{49}$ The caption read: 'Ticking time bomb: Maj. Nidal Hasan in security-camera footage taken at a 7-Eleven just hours before his rampage.' Below the photograph was the headline 'Officials admit shrugging off gunman's e-mails to al-Qaeda'. The story reported:

The FBI last night said Hasan - who faces a court martial - first turned up on its radar in December 2008.

That's when 10 and 20 e-mails were sent by Hasan to several terror-related Islamic figures, including Anwar Aulaqi [sic], a radical imam from Virginia who has been 
openly propagandizing for al Qaeda in Yemen and who had ties to several of the 9/11 hijackers. ${ }^{50}$

In the same issue, it appeared through the discourse on the editorial and the letters pages that Hasan was being tried by the media. The editorial was critical of the FBI and army investigators who had earlier ignored Hasan's case. It was appreciative of Senator Joe Lieberman, who speculated about Hasan's link to terrorism. It pointed out that 'one doctor who studied with Hasan said that he "would frequently say he was a Muslim first and an American second"'.51 He and others reportedly complained to higher authorities but no action was taken against Hasan. The editorial quoted Hasan's classmate's comments: 'We questioned how somebody could take an oath of office and be an officer in the military and swear ... to defend America against all enemies, foreign and domestic' with that attitude..$^{52}$ Out of thirteen printed letters to the editor there was only one that defended Muslims: 'To blame the whole Islamic world for a terrorist attack by one individual is wrong. ${ }^{53}$ Other letters were critical of Muslims, Islam and other media.

In the same issue (10 November 2009), columnist Ralph Peters was critical of the people (including those in the media) who advocated caution in labelling the attack as a Muslim or terror attack. ${ }^{54}$ An opinion piece by Rich Lowry, which ran under Peters's column, was critical of Time magazine for blaming the stressful environment of Fort Hood and suggesting that the frequent deployments may have led to Hasan's act..$^{55}$ Lowry was also critical of a New York Times piece that raised the possibility that Hasan may have contracted post-traumatic stress disorder by treating patients who were very distressed. On 13 November 2009, in his opinion piece, Paul Sperry was critical of CAIR and some sections of the media that gave Muslims a voice during the Fort Hood crisis. Sperry wrote:

For years, our media and government routinely accepted and even promoted the Washington-based Council on American-Islamic Relations as a legitimate voice of Muslim Americans, buying into its claim to be the Muslim ACLU.

In fact, CAIR is a radical Saudi-funded front group founded by leaders of the terror-supporting Muslim Brotherhood to infiltrate Washington and defend extremists. More than a dozen of CAIR's leaders have been jailed or otherwise implicated in support of terrorism - yet its spokesmen until recently were welcomed in the highest corridors of power...

In the wake of the Fort Hood killings CNN, PBS, Fox, MSNBC and other networks immediately put CAIR's leaders on the air - where they predictably insisted the attack had nothing to do with Islam and warned that any 'Islamophobes' who make that obvious connection are inviting violent 'backlash' against Muslims. ${ }^{56}$

Finally, in his opinion piece Bill O’Reilly concluded: 
Fort Hood isn't a 'tragedy' ... Hasan is a hater driven by a fanatical Islamic viewpoint ... Americans are at risk because Muslim terrorists want to kill us. That doesn't mean most Muslims subscribe to jihad, but it does mean the problem is exclusively Muslim. ${ }^{57}$

\section{Further analysis of the Fort Hood media coverage}

Nizam (male, 20, US born of Bangladeshi background, national identity: 'I feel more American') observed:

Yeah, the Fort ... Fort Hood kind of solidifies my argument as the news media [television] being a source of entertainment and what you will see, the first thing they show over and over again, repeatedly scene after scene - we're talking about this Nidal Hasan guy - he's shown buying a coffee. Well, the first week I thought it was a false story, just because they showed this man with an Arab suit, with Arab dress on, and him buying coffee. Now this is totally unrelated to the actual topic, which is him murdering thirteen people, now why would you show a Muslim man in a type of Arab dress when this is totally unrelated to the story? You have a crazy guy, not a Muslim, and they're showing that scene over and over ... This is how they perhaps construct a Muslim image as the 'other'. (Interview, New York, November 2009)

While Nizam made his observation about the electronic media, I examined the Fort Hood news representation in the print media. For example, there were reports of prayers for the departed souls and the alleged gunman (Major Hasan) in a church, and some newspapers explicitly printed photographs of the church ${ }^{58}$ though there was no report of mosques where Muslims had prayed for the Fort Hood victims. For example, members of the South Florida Muslim community expressed their concerns, and prayed for peace and for the victims at Fort Hood in the Friday prayer (the day after the shooting incident) in the mosques of southern Florida. The president of CAIR South Florida, Muhammed Malik, also urged mosques to pray for the victims. Malik said, 'It is totally unacceptable in Islam; any person of conscience will condemn that and we condemn that.' A former Muslim American Navy officer, Yusuf Mendez, said, 'It is a tragedy. You know in the Quran it says whenever you kill one person you kill all mankind. It is our duty to safeguard the community in which we live.' Mendez also pointed out that tens of thousands of Muslims serve in the US military. The Muslim community in southern Florida organised a candlelight vigil on the following Monday, and they urged Christians and Jews to join them. ${ }^{59}$

In Chapter 3, I discussed that the number of Muslims serving in the US armed forces is low compared to the total population. In November 2009, the New York Times reported, 'Some 3,557 military personnel identify themselves as Muslims among 1.4 million people in the active duty population, according 
to official figures. [But] Muslim advocacy groups estimate the number to be far higher, as listing one's religious preference is voluntary' ${ }^{60}$

Hasan's religion also sparked a lot of controversy on some mainstream American talkback shows across the country. For example, Jimmy Cefalo's radio show on 610 WIOD in southern Florida included some callers who commented on Muslims, for example, 'We are at war against people that declared war against us. We didn't declare war against them. They declared war against us.' Jimmy Cefalo asked his listeners, 'No Muslims should be allowed in the military, is that the idea?' A female caller replied, 'Exactly, they are going to turn on you anyway sooner or later. ${ }^{\prime 61}$ The executive director of CAIR, Nihad Awad, commented on MSNBC live news after the Fort Hood shooting incident:

I am not really happy that his [Hasan's] religion is becoming the subject when we have crimes committed against our soldiers and against our civilians inside the United States and outside the United States and how the religion, if it plays by the motives of those who are committing these acts, it does not become a story in the United States press except when he or she is a Muslim and it is our unfortunate [sic] and even this guy uttered this word Allabu Akbar, God is Great ... this is an isolated incident by a disturbed individual ... This also reminds me of ... the abortion bomb ... he did it in the name of Christianity or Christian, he became the subject of the press ... even if they claim their religious affiliation, I don't think we should play into their hands. ${ }^{62}$

\section{Times Square bombing attempt, 2 May 2010}

Time printed a detailed report on Faisal Shahzad's bombing attempt in Times Square in Manhattan:

The explosion [if it had happened], lasting only a few seconds, would have created a thermal ball wide enough to swallow up most of the intersection. A blast wave would have rocketed out in all directions at speeds 12,000 to $14,000 \mathrm{ft}$ per sec. (3,700 to $4,300 \mathrm{~m}$ per sec.); hitting the surrounding buildings, the wave would have bounced off and kept going, as much as nine times faster than before. Anyone standing within $1,400 \mathrm{ft}(430 \mathrm{~m})$ - about five city blocks - of the explosion would have been at risk of being hit by shrapnel and millions of shards of flying glass. The many who died would not die prettily ... Indeed, shortly after the incident in Times Square, Pakistan's Tehrik-e-Taliban claimed it was behind the plot. ${ }^{63}$

Time's eight-page coverage discussed Shahzad's history in the USA and revealed that he lived in an affluent suburb but later lost his job. Time also justified the wars in Afghanistan and Iraq and drone attacks in Pakistan because 'while... drones in Pakistan have killed many would-be terrorists, those who continue to operate do so more independently', and gave the examples of Nidal Hasan 


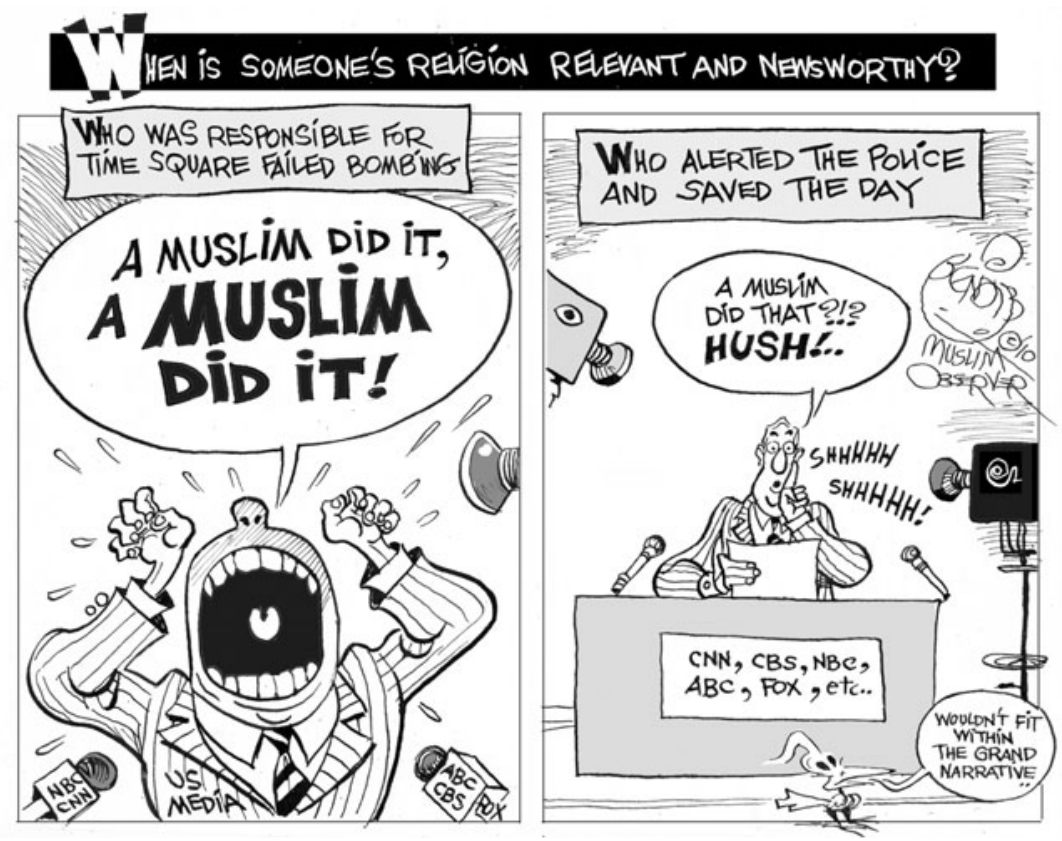

Figure 4.1 When is someone's religion relevant and newsworthy?

From Muslim Observer, 16 May 2010

(C) Khalil Bendib, all rights reserved.

in Fort Hood and Umar Farouk Abdulmutallab, who allegedly attempted to blow up a flight as it approached Detroit in December 2009.64 Overall, Time managed to generate fear among some readers as it published photographs of alleged and convicted terrorists (all bearing Muslim names), and mentioned that terrorist groups in Pakistan were working globally. ${ }^{65}$

The fears and concerns of both Muslims and non-Muslims were expressed later in letters to the editor. For example, Kenneth Lee wrote of his concern 'about the legal immigrants who want to harm us rather than the illegal immigrants who only want a job'. ${ }^{66}$ Lynne Gaylor stated, 'We have always been a nation that is willing to help other countries, but what do we get in return? A stab in the back.' ${ }^{67}$ At the same time the Faisal Shahzad incident made some American Muslims feel vulnerable. As Reem Bakker wrote, 'The worst thing that came from Shahzad's botched bombing is that it further damaged the reputation of Muslims in the U.S. ${ }^{68}$

Another Muslim, Zoya Mehmoud, appealed to the wider society: 'Although the events in Times Square were certainly frightening, the political backlash against Pakistanis and Muslims was even more so ... Don't make us pay for the mistakes of others. ${ }^{69}$ Finally, a Muslim from Pakistan, Syed Naheer Ameer, wrote: 
Time's article on the Times Square incident is rather biased. There was a great deal mentioned about the tragic loss of life that could have occurred if the explosion had taken place on May 1, but little about the many deaths suffered by civilians at the hands of drone missile attacks in Pakistan. Is a Pakistani life not worth the same as that of a U.S. citizen? You should be bridging the gap between Muslims and the West instead of heightening tension. ${ }^{70}$

\section{Pipe bomb blast, 10 May 2010}

On 10 May 2010 a pipe bomb was detonated at the Islamic Center of Northeast Florida (a mosque in the Southside district of Jacksonville). It went off during evening prayers, and it was powerful enough to send shrapnel flying 100 metres. Worshippers at the centre said they heard a loud noise outside the mosque and went outside where they found fire engulfing a rear emergency exit. The flames were put out with a fire extinguisher. The case was treated as a hate crime. ${ }^{71}$

An observer of both the Times Square and the pipe bomb incidents, Hesham Hassaballa, was surprised that the Times Square bombing attempt was considered an act of terrorism while the pipe bombing was first treated as a hate crime and later 'as a possible act of domestic terrorism'. Hassaballa commented, 'What if a pipe bomb exploded in Times Square? Or outside a church? Would this be called terrorism? Of course it would ... and it should. So should this attack on the Jacksonville, FL mosque. ${ }^{72}$

A year later, an alleged perpetrator of the pipe bombing, Sandlin Matthews Smith, of St Johns County, Florida, was shot and killed when he pulled a gun on agents who were trying to arrest him in Oklahoma. ${ }^{73}$ When the mosque bombing incident happened in May 2010, I was in the US and keenly observed both the print and electronic media, but this pipe bombing surprisingly was not given as high a profile as other news such as the Fort Hood shooting incident.

\section{Arizona shooting, 8 January 2011}

On 8 January 2011, a 22-year-old man named Jared Loughner killed six people (including a child) and injured thirteen others (including Arizona Democrat Congresswoman Gabrielle Giffords). The shooting occurred when Giffords was talking to two constituents at a 'Congress on Your Corner' event outside a grocery store. ${ }^{74}$ The electronic media selectively chose not to racially profile the perpetrator. And Fox News's Glenn Beck programme was sympathetic to the victims and apparently overprotective of the conservative leaders who were considered by some people to be inadvertent instigators of the shooting incident.

This man [the Arizona perpetrator] wasn't a right-wing nutjob. But he also was not a left-wing nutjob. He was just a nutjob. 
There are people who are nuts and will do violent things and they will do them in somebody else's name because they're nuts. There's also people like the nineteen hijackers who took down the World Trade Center in the name of Allah. Is Allah responsible? Or, hey, how about the religion that these guys go to? No, no, no, no, no, no, we are told by the media. These nineteen hijackers - no, no, no. ${ }^{75}$

I found the analogy of the nineteen hijackers in the Twin Towers attacks completely irrelevant. It once again reminded the audience that 'we' are not a threat but 'they' [Muslims] are.

\section{Christian-Muslim dichotomy in the media}

Fifty-two participants in this study particularly observed that the American media has often portrayed Muslims solely through the prism of extremism and terrorism. The media discourse on Muslims tends to transpose Muslims as 'bad Muslims'. In most instances, when the perpetrators are not Muslims, the media do not identify their religion at all. Lateefa (female, 25, African American, national identity: American) observed:

Every day someone's committing a crime, and most of the people in the United States ascribe to some religion, but it's never said a Christian does such and such and such, a Jewish person does such and such and such, but when a Muslim does it that's one of the first things they say, 'He is a Muslim', and to me that's, in itself, just bias. (Interview, Florida, March 2010)

For example, on 18 February 2010, Joseph Andrew Stack crashed a plane into the IRS office in Austin, Texas, where 190 employees were working. Stack was angry with the federal tax authorities. Apparently, he left a suicide note that criticised the IRS and declared: 'Violence is the only answer.' Apart from the pilot, there were no casualties. The Austin police chief, Art Acevedo, 'said there was no cause for concern and assured residents that it was an isolated incident'. The White House commented, 'The crash did not appear to be an act of terrorism. ${ }^{76}$ The media did not spend much time on this issue. Ten participants in this study (see Table 4.1) considered this episode represented a 'double standard' because there was no mention of 'terrorism' and no discussion of the religion of the perpetrator.

Muslim leader Zahed (male, over 30, African American, national identity: 'black American') mentioned that the radical Christian militia group Hutaree, charged with plotting to kill police in Michigan and wage war on the federal government, were not identified as Christians:

We have, from not just right-wing TV like Fox National News, but even sometimes ... local stations through ignorance misrepresent issues relating to the Muslim com- 
munity or they use inaccurate nomenclature to describe us or news stories. Like, for example, they'll call a Muslim like this guy 'the Christmas Day bomber', and 'Islamic radical' or a 'Muslim terrorist', but then with the Christian militia group they won't even mention Christianity ... Hutaree, this is just one example. (Interview, Michigan, May 2010)

I checked Zahed's comment about Hutaree (meaning 'God's warrior'), and found that on 28 March 2010 nine members of a Christian militia group in Michigan were indicted after a federal investigation into an alleged plot to kill a police officer and then attack the funeral with bombs in the hope of starting an uprising against the government. They were arrested following raids in Michigan, Indiana and Ohio. Hutaree's doctrine alludes to the end of the world: 'When the time comes for those without enough faith, they will fall to the Anti-Christ's doctrine. And it will make perfect sense to the whole world; even the elect. ${ }^{77}$ An online video depicted men armed with rifles dressed in camouflage and an arm patch with the Hutaree insignia of a red and brown cross flanked by diagonal brown stripes. It also showed gunmen practising shooting from behind a car, and conducting military manoeuvres in a wooded area. ${ }^{78}$

On 12 February 2011, I looked into the Factiva database (which has a wide-ranging collection of newspapers) and typed 'Hutaree' to see if it was associated with Christianity. There were 753 news items from 28 March 2010 to 27 January 2011. In my survey I found some overseas media in Australia, Canada, India, Thailand and New Zealand had printed headlines that included the words 'Christian militia'. But since my discussion is on American Muslims, I focused on the American media and found that only 2 per cent of the American media included the word 'Christian' or its derivatives in the headlines in their reporting. Here is the sample:

- 'God's warrior Christian militia' (Nightline, ABC, 29 March 2010)

- 'Christian militia members arrested; Tea Party still influential?' (Campbell Brown, CNN, 29 March 2010)

- 'FBI has 3 raids; Christian militia a reported target' (St Louis PostDispatch, 29 March 2010)

- 'Stepmother says she helped coax Michigan Christian militia member into surrender to FBI' (Associated Press Newswires, 30 March 2010)

- " "Christian warriors" indicted; help for homeowners; bullied to death?; Karl Rove heckled; Russian subway suicide attacks; forced to pay rent' (CNN Newsroom, CNN, 30 March 2010)

- 'Militant Christians held in murder plot' (Financial Times (USA), 30 March 2010)

- 'Michigan Christian militia group appears in federal court' (Voice of America Press Releases and Documents, 30 March 2010) 
- 'Feds had eye on "Christian warriors"' (Knoxville News Sentinel (TN), 31 March 2010)

- 'Beware of false Christians bearing arms' (Ventura County Star (Camarillo, CA), 2 April 2010)

- 'Beware of false Christians bearing arms' (Times Record News (Wichita Falls, TX), 4 April 2010)

- 'Christian terrorists?' (Christian Century (Chicago), 4 May 2010)

- 'Violence cloaked in Christianity' (Virginian-Pilot \& Ledger-Star (Norfolk, VA), 9 April 2010)

- 'Giving Christians a bad name' (Las Vegas Review-Journal, 11 April 2010)

- 'Christian terrorism' (Abilene Reporter-News (TX), 11 April 2010); also published in another newspaper: 'Pitts: Christian terrorism' (Daily Camera (Boulder, CO), 12 April 2010)

- 'Christian militia case defendant lived in Tukwila' (Associated Press Newswires, 14 April 2010)

- 'Christian bows out of hate-filled take on faith' (Sunday News (Lancaster, PA), 25 April 2010)

- "U.S. "Christian militia" members on trial accused of plotting uprising against govt; advance media information; future news item; U.S. District Court for the Eastern District of Michigan' (Precise Media Planner, US District Court for the Eastern District of Michigan, Detroit, 9 December 2010). ${ }^{79}$

In the 753 Factiva American news items, I found some media outlets that were critical of Hutaree but refrained from using the word 'Christian' in their headlines. For example, USA Today reported:

Charges that nine members of a Michigan militia group were cooking up a crackpot plot to kill police officers and wage war on the United States should come as a surprise to no one. We've seen this kind of lunacy before, most tragically with the 1995 bombing of the federal building in Oklahoma City.

But the scheme is a reminder that well-armed people simmering with hatred are ever present and easily stoked to violence, that they're not easily typed by race or ethnicity, and that terrorism is sometimes homegrown.

The group - which dubbed itself 'Hutaree', a word it said meant 'Christian warriors' - viewed local law enforcement as the 'foot soldiers' of the federal government, and according to prosecutors, it planned to attack a local officer, then detonate explosives to murder those gathered for that officer's funeral. Their hope was to incite an anti-government uprising. ${ }^{80}$

The Daily News in Bowling Green, Kentucky was also critical of Hutaree but refrained from using the words 'Christian terrorists'! 
These people are just as bad as the terrorists we are fighting in Iraq and Afghanistan. What is even more twisted about this group is that its name, Hutaree, means 'Christian warrior.' The group quotes several Bible passages and declares: 'We believe that one day, as prophecy says, there will be an Antichrist ... Jesus wanted us to be ready to defend ourselves using the sword and stay alive using equipment.' What Jesus says in the Bible can be subject to different interpretations, but to reach the conclusions these folks did defies belief. These suspects are, quite frankly, crazy and should provide a wake-up call to us all that people who wish to do us harm aren't just overseas. Some terrorists are homegrown and living among us. ${ }^{81}$

The New York Post was sympathetic towards the Christian militia. It compared the Hutaree militia with the 9/11 plotters and Fort Hood gunman, and declared that Hutaree was a lesser threat:

Alas, the Hutaree case is likely to boost the bogus narrative that such antigovernment militias represent fundamentally the same threat as Islamist terrorists ... But one need only contrast the wild fantasies indulged by the Hutaree kooks with the lethal calculation of killers like the 9/11 plotters or the Fort Hood gunman (not to mention their respective body counts) to understand the radical difference between the two threats. One consists of the dedicated agents of a ruthless, religion-driven ideology. The other: a few guys in the woods with guns. The Obama administration - Attorney General Eric Holder and Homeland Security Secretary Janet Napolitano, in particular - needs to keep its eyes on the ball. ${ }^{82}$

\section{Sympathetic tones towards Muslims}

In the 753 Factiva American news items, I found three columnists (Omar Sacirbey of the Houston Chronicle, Leonard Pitts Jr of the Virginian-Pilot \& Ledger-Star and an anonymous writer in Christian Century magazine) who were critical of the media or mainstream Americans' selective use of the word 'terrorism'. For example, in his piece 'Muslims see double standard in "terrorist" label' Sacirbey observed that after the Hutaree arrests some Muslim leaders pointed out the 'double standards' of some American media. ${ }^{83}$ They observed that the 9/11 Twin Towers attack was labelled an act of 'Islamic terrorism'. With regard to Hutaree, the media avoided the words 'Christian terrorism'. Sacirbey cited Alejandro Buetel, the government liaison officer for the MPAC in Washington, who commented, 'In cases of violence committed by Muslims, when it's politically motivated, yes, call it Muslim terrorism. But when other faiths or ideologies commit violence, it has to be the same. We're calling for consistency.' Similarly, on the Huffington Post website, the Muslim commentator Yasmin Mogahed (cited by Sacirbey), pointed out that after the Hutaree arrests she did not see any expert on TV exploring whether Christian doctrine condones violence, yet after any Muslim-related incident the media 
rushes to bring in experts to search the Quran for verses condoning violence. Mogahed said, 'If there's news of a Muslim terrorist, Islam becomes complicit in the crime. Yet few people are going to accuse Christianity of motivating the terrorism of the Hutaree militia.' As discussed earlier, I found only 2 per cent of the 753 Factiva American news items (from 28 March 2010 to 27 January 2011) use the label 'Christian' or 'Christianity' in their headlines.

Similarly, Leonard Pitts Jr was critical of Americans who avoid the term 'terrorism' for Christian violence. He gave examples of 'Christian terrorism':

From Eric Rudolph's bombing of the Atlanta Olympics, a gay nightclub and two abortion clinics; to the so-called Phineas Priests who bombed banks, a newspaper and a Planned Parenthood office in Spokane, Wash.; from Matt Hale soliciting the murder of a federal judge in Chicago; to Scott Roeder's assassination of abortion provider Dr. George Tiller; from brothers Matthew and Tyler Williams murdering a gay couple near Redding, Calif.; to Timothy McVeigh destroying a federal building and 168 lives in Oklahoma City, we have seen no shortage of 'Christians' who believe Jesus requires - or at least allows - them to commit murder.

If federal officials are correct, we now have one more name to add to the dishonor roll. That name would be Hutaree. ${ }^{84}$

Pitts observed that many Americans accept that it would be unfair to tarnish all Christians as 'terrorists' for these acts. He said, 'We are conditioned [by the media] to think of terror wrought by Islamic fundamentalists as something strange and alien and other ... we are pleased to believe, [there is] a hard, immutable line between us and Them.' Similarly, the anonymous writer in Christian Century commented:

The Christian militia group known as the Hutaree, whose leaders were arrested by the FBI during Holy Week, is fond of quoting Christian scripture. Its Web site features this line from Jesus in the Gospel of John: 'Greater love hath no man than this, that he lay down his life for his friends.' The mission of the group is spelled out: 'Preparing for the end time battles to keep the testimony of Jesus Christ alive.' ... To the vast majority of Christians, the Hutaree represent an appalling distortion of Christian beliefs... The discomfort is understandable - and educational, for it gives Christians a chance to experience the incongruity many Muslims feel when the media refer to Muslim terrorists. ${ }^{85}$

\section{Embarrassed to be Christians}

Like the mainstream Muslims who found themselves tarnished by the 9/11 Twin Towers attacks and after the failed terrorist plot by Faisal Shahzad, ${ }^{86}$ some Christians felt the same about the Hutaree incident. For example, the 
Reverend Rachel Hackenberg was critical of some Christians:

I am frustrated and fed up with groups like Westboro Baptist Church that continue to call themselves 'Church' or people like those in the Hutaree Militia who call themselves 'Christians' ...

I am embarrassed and appalled as a Christian to carry the same name as Pat Robertson, James Dobson, Diane Gramley (of 'Out in the Silence' fame, or is it infamy?), and the like. Hatred and violence and the politics of fear were never, never part of the ministry of Jesus, yet often in the public arena when someone mentions 'Christian,' people think of these persons first and foremost - before Mother Teresa, before Martin Luther King Jr., before their local churches that contribute to food banks and organize clothing drives and serve great spaghetti dinners. ${ }^{87}$

Likewise, in his opinion piece 'Giving Christians a bad name', J. C. Watts stated:

Both groups - the Hutaree in Michigan and the Phelps-led Westboro Baptist Church in Kansas - bring to mind the Ku Klux Klan parading in masks and robes, terrorizing and murdering minority families across the nation on Saturday night, and praising the Lord on Sunday morning in their local church pews.

Where do these people come off calling themselves Christians? ... Every Christian in America should be outraged at this 'Christian militia' group in Michigan, the KKK and the Phelps family. ${ }^{88}$

And in a letter to the Commercial Appeal in Memphis, Vaughn Denton wrote:

The men who call themselves a Christian Militia Group who were arrested by the FBI in raids over the weekend of March 27 in Michigan, Indiana and Ohio were wicked men ... True believers in Christ are not 'white supremacists' and right wing extremists, nor are we Ku Klux Klan members. ${ }^{89}$

\section{Not all media is bad}

Table 4.1 shows that nineteen participants in my study held positive views about the American media. For example, Irfan (male, 25, overseas born of Pakistani background, national identity: Pakistani American) said, 'I don't watch Fox ... I don't watch CNN ... I love business so I watch CNBC all the time. I read the Wall Street Journal every day ... I read the business news' (interview, Massachusetts, November 2009). Benazir (female, 17, US born of Indian background, national identity: American Indian) said, 'I like watching MSNBC because I think they're better than ... But I think they're more open and accepting and I think Fox is very biased' (interview, Massachusetts, November 2009). Dina (female, 18, US born of Trinidadian background, 
national identity: Trinidadian Muslim) had a positive firsthand experience and she shared her favourable opinion of one particular newspaper:

It was my 8th-grade year. I was president of student council for my 8th-grade year. And we worked with the city of ... police department to collect school supplies to send to Afghanistan. And the Sun-Sentinel actually interviewed me and they posted up a story, 'Helping hands, kids helping kids'. And they had troops from Afghanistan send us pictures of when the kids actually got the school supplies. (Interview, Florida, March 2010)

Ameena (female, 20, US born of Egyptian background, national identity: Arab American Muslim) said, 'I watch Al Jazeera. I try to watch BBC the most. I don't watch CNN, I don't watch Fox News because it is so biased.' She added: 'But definitely, I appreciate some journalists who try to see both sides, try to listen to other people's opinions and get the full story, but for the most part, yeah, American media, I don't watch it' (interview, Florida, March 2010). Ameena implied that other outlets such as the British media and the Qatari media showed both sides of the story. Yet there were some participants who appreciated some CNN and Fox programs. For example, Ruhee (female, over 30, overseas born of Palestinian background, national identity: 'Muslim, first and foremost, then Arab American') spoke of the three-part CNN documentary God's Warrior, aired in August 2007. The documentary focused on the three Abrahamic religions (Judaism, Christianity and Islam) in the United States, Europe and the Middle East. Ruhee said:

In their documentary they shed light on post-9/11 and the Muslims here. So they talked about a lot of people who converted to Islam weeks after 9/11 so you hear a lot of positive. You know in this society, you'll always hear of the positive and negative and for me I try to dwell on the positive. (Interview, Michigan, April 2010)

It is interesting to note that a few participants in the 20-30 age group spoke positively of Jon Stewart's Daily Show on Comedy Central. Sonia (female, 20, US born of Egyptian origin, national identity: Muslim) said:

If you think of people like Jon Stewart, he's very positive and he's a liberal and he kind of shows both sides and sometimes it depends on what the topic is but, you know, compared to like five or six years ago, it's gotten better. (Interview, Florida, March 2010)

\section{Conclusion}

In this chapter, I have discussed how the participants felt about the US media. Since many respondents had negative views about some media outlets, I 
decided to examine the print media on pertinent topics. For news about Muslims, I investigated print media representation of the Fort Hood incident in detail. I briefly examined other incidents that involved both Muslim and non-Muslim perpetrators, such as the Times Square bombing attempt, the pipe bomb blast, the Arizona shooting and the Hutaree case. By comparing the nonMuslim/Christian incidents such as the pipe bomb blast, the Arizona shooting and the Hutaree case, I was able to test the validity of the participants' view that the media is biased, that it labels Islam/Muslims and so on. Of course, the Fort Hood shooting incident, the Arizona shooting, the Times Square bombing attempt and the pipe bombing in Florida were horrendous. The Hutaree Christian militia's alleged plot against the government was quite serious. Some print media sources on Hutaree included 'Christianity' in their headlines, but the news was not spread nationally as is commonplace with Muslim cases. (I only came to know about the Hutaree militia incident through a Muslim leader's interview in Michigan.)

Fifty-two participants mentioned that the media has positive or somewhat positive attitudes, and eight respondents expressed the opinion that Muslims should get involved in the media to give a better Muslim representation. I will explore this topic in the Conclusion.

Overall, the media involves a wide range of outlets. From my brief examination of the print media, I found that, when the perpetrator is a Muslim, there is a tendency for journalists to connect the incident to the 'Muslim other' and blow their news reporting up out of all proportion to the event.

\section{Notes}

1. Pew Research Center, 'Muslim Americans: No Signs of Growth in Alienation or Support for Extremism', Pew Research Center website, 30 August 2011, http:// people-press.org/2011/08/30/muslim-americans-no-signs-of-growth-in-alienationor-support-for-extremism/, accessed 22 May 2012. The percentages from 2011 (55 per cent unfair, 30 per cent fair, 25 per cent unsure/depends) add up to 110. This is how they appear on the Pew website.

2. Ibid.

3. USA Today, New York Times, Boston Globe, Boston Herald, Daily News and New York Post.

4. Edward Said, Covering Islam: How the Media and the Experts Determine How We See the Rest of the World, rev. edn (New York: Viking, 1997), pp. ix-xvi.

5. E. Ghareeb, 'The Middle East in the U.S. Media', Middle East Annual: Issues and Events 3 (1983), pp. 185-210.

6. Ahmadullah Siddiqi, 'Islam, Muslims and the American Media', in Amber Haque (ed.), Muslims and Islamization in North America: Problems and Prospects (Beltsville, MD: Amana, 1999), pp. 203-29, see p. 210.

7. Ibid. pp. 211-13. 
8. Ibid. p. 212.

9. Jeremy Earp and Sut Jhally (dir.), Reel Bad Arabs: How Hollywood Vilifies a People, DVD (Northampton, MA: Media Education Foundation, 2006).

10. Saud Joseph, Benjamin D’Harlingue and Alvin Ka Hin Wong, 'Arab Americans and Muslim Americans in the New York Times, before and after 9/11', in Amaney Jamal and Nadine Naber (eds), Race and Arab Americans before and after 9/11: From Invisible Citizens to Visible Subjects (Syracuse, NY: Syracuse University Press, 2008), pp. 229-75, see pp. 234-5.

11. Ibid. pp. 236-7.

12. Laurie Goodstein, 'In U.S., echoes of rift of Muslims and Jews', New York Times, 12 September 2001, p. 12; see also Joseph, D'Harlingue and Wong, 'Arab Americans and Muslim Americans', pp. 240-1.

13. Goodstein, 'In U.S., echoes of rift of Muslims and Jews'.

14. Jane I. Smith, Islam in America, 2nd edn (New York: Columbia University Press, 2010), p. 190.

15. Ibid, p. 190; see also Wayne Kopping (dir.), Obsession: Radical Islam's War against the West, Pulsar Productions, Liberty Film Festival, October 2005.

16. Smith, Islam in America, p. 190.

17. Ibid. pp. 187-8.

18. Jennifer Steinhauer, 'Gunman kills 1 and wounds 5 at Florida office', New York Times, 7 November 2009, p. 9.

19. 'Tragedy at Fort Hood: rampage tears into soldiers' sanctuary', USA Today, 6-8 November 2009, p. 1.

20. 'Top brass warn against anti-Muslim backlash', USA Today, 9 November 2009, p. 1.

21. 'Red flags at Fort Hood', USA Today, 9 November 2009, p. 10.

22. 'FBI: Fort Hood suspect had ties to radical imam', USA Today, 10 November 2009, p. 2.

23. Lucinda Roy, 'Don't let the shooters win', USA Today, 10 November 2009, p. 11.

24. James Alan Fox and Jack Levin, 'Fort Hood tragedy: terror or typical workplace violence', USA Today, 11 November 2009, p. 21.

25. Debra Adkins, Roanoke, VA, 'Writing on the wall', Letters to the Editor, USA Today, 12 November 2009, p. 10.

26. James Dao, 'Told of war horror, gunman feared deployment', New York Times, 6 November 2009, pp. 1, 16.

27. Clifford Krauss and James Dao, 'Details trickle out as army tests sole-killer theory', New York Times, 7 November 2009, p. 1.

28. Ibid.

29. James C. McKinley Jr and James Dao, 'After years of growing tensions, 7 minutes of bloodshed', New York Times, 9 November 2009, p. 1.

30. Andrea Elliott, 'A hard time for Muslims to serve their country, especially after shootings', New York Times, 9 November 2009, p. 17.

31. Ibid. 
32. Thomas M. Doran, Plymouth, MI, 'As the nation grieves over Fort Hood', Letters to the Editor, New York Times, 10 November 2009, p. 30.

33. David Brooks, 'The rush to therapy', New York Times, 10 November 2009, p. 31.

34. Ibid.

35. Abroo Shah, Westfield, NJ, 'The search for the "why" of Fort Hood', Letters to the Editor, New York Times, 12 November 2009, p. 30.

36. April Castro and Devlin Barrett, ' 12 killed in rampage at Fort Hood', Boston Globe, 6 November 2009, p. 6.

37. 'Suspect feared deployment, relative says', Boston Globe, 6 November 2009, p. 6.

38. Greg Jaffe and Dan Eggen, 'As shots rang out, she answered call', Boston Globe, 7 November 2009, p. 1.

39. Mike Baker and Brett J. Blackledge; 'Suspect a study in contrasts', Boston Globe, 7 November 2009, p. 6.

40. 'Muslim leader troubled by talks with suspect', Boston Sunday Globe, 8 November 2009, p. 6.

41. Devlin Barrett, 'Fort Hood suspect reached out to radical imam', Boston Globe, 10 November 2009, p. 2.

42. 'Vox Op', Letters, Boston Globe, 10 November 2009, p. 15.

43. 'Docs were wary of alleged shooter', Boston Herald, 12 November 2009, p. 19.

44. 'Face to face with evil', Daily News, 9 November 2009, p. 1.

45. 'Fanaticism hits home', Daily News, 10 November 2009, p. 22.

46. Ibid.

47. Charles Krauthammer, 'Medicalizing mass murder', Daily News, 13 November 2009, p. 27.

48. 'Fort Hood massacre, mosque of evil, killer's 9/11 terror link', New York Post, 9 November 2009, p. 1.

49. 'Officials admit shrugging off gunman's e-mails to al-Qaeda', New York Post, 10 November 2009 , p. 5.

50. Ibid.

51. 'Eyes wide shut', New York Post, 10 November 2009, p. 28.

52. Ibid.

53. Peter Manasse, Monaco, 'When terror hits home, America's PC suicide', New York Post, 10 November 2009, p. 28.

54. Ralph Peters, 'Fudging the facts on Fort Hood', New York Post, 10 November 2009, p. 29.

55. Rich Lowry, 'Sorry, this killer's no victim', New York Post, 10 November 2009, p. 29.

56. Paul Sperry, 'Moderate terror pals', New York Post, 13 November 2009, p. 31.

57. Bill O'Reilly, 'Obama's problem with reality', New York Post, 13 November 2009, p. 31.

58. E.g. Boston Globe, Daily News, 9 November 2009.

59. $610 \mathrm{WIOD} / \mathrm{CBS} 4$ news, cited in 'South Florida Muslims pray for peace', CAIR-FL 
video, 6 November 2009, http://www.youtube.com/watch?v=iuGHJbpN8rs, accessed 22 May 2012.

60. Andrea Elliott, 'Complications grow for Muslims serving in the U.S. military', New York Times website, 8 November 2009, http://www.nytimes.com/2009/11/09/ us/09muslim.html? pagewanted=all, accessed 28 May 2012.

61. Ibid.

62. 'CAIR not happy Hasan's Islamic faith is discussed; "so what" if he said "Allahu Akbar!" ', CAIR video, 6 November 2009, http://www.youtube.com/watch?v=3cf saByxg9Q\&feature=related, accessed 22 May 2012.

63. Howard Chua-Eoan, 'Broadway bomber', Time, 17 May 2010, pp. 15, 17.

64. Ibid. p. 18.

65. Ibid. pp. 14-21.

66. Kenneth Lee, Raytown, MO, Letters to the Editor, Time, 7 June 2010, p. 4.

67. Lynne Gaylor, Clearfield, PA, Letters to the Editor, Time, 7 June 2010, p. 4.

68. Reem Bakker, New York, NY, Letters to the Editor, Time, 7 June 2010, p. 4.

69. Zoya Mehmoud, Alexandria, VA, Letters to the Editor, Time, 7 June 2010, p. 4.

70. Syed Naheer Ameer, Karachi, Pakistan, Letters to the Editor, Time, 7 June 2010, p. 4.

71. Keith Olbermann, 'There is no "Ground Zero mosque"', MSNBC TV website, 16 August 2010, http://www.msnbc.msn.com/id/38730223/ns/msnbc_tv-count down_with_keith_olbermann/, accessed 22 May 2012.

72. Hesham A. Hassaballa, 'Terror double standard (pipe-bomb explosion @ Florida mosque vs. Times Square plot)', MuslimMatters website, 18 May 2010, http:// muslimmatters.org/2010/05/18/terror-double-standard/, accessed 22 May 2012.

73. 'FBI: Fla. bombing suspect killed in Okla. was paranoid that cops were after him, hated Muslims', Associated Press Newswires, 6 May 2011.

74. Jim O'Sullivan, 'Arizona shooting rocks the political world', National Journal, 8 January 2011.

75. Glenn Beck, Fox News, 10 January 2011.

76. 'Texas pilot air attack on US office', BBC News website, 18 February 2010, http:// news.bbc.co.uk/2/hi/8522746.stm, accessed 22 May 2012.

77. Mark Reiter and Christopher D. Kirkpatrick, ' 9 alleged militia members indicted for plotting to kill police', The Blade (Toledo, OH), 29 March 2010.

78 Ibid.

79. Retrieved through Factiva database, accessed 27 January 2011. These headlines with the label 'Christian' did not appear in the Factiva database: 'Feds: Christian militia needed to be "taken down"' (Boston Globe, 30 March 2010); 'Christian Militia members charged with plots to kill police officers' (USA Today, 29 March 2010); 'Hutaree Christian militia plotted to kill cops in name of "top general" Jesus Christ: FBI', (Daily News (New York), 29 March 2010).

80. 'Militia arrests show there's no stereotyping terrorism', USA Today, 31 March 2010, p. 10. 
81. 'Terror plot shows it exists here as well', Daily News (Bowling Green, KY), 1 April 2010.

82. 'Gunmen in the woods', New York Post, 31 March 2010, p. 28. This was also cited on the Newscorpwatch website at http://newscorpwatch.org/blog/201003310003, accessed 22 May 2012.

83. Omar Sacirbey, 'Muslims see double standard in "terrorist" label', Houston Chronicle, 9 April 2010, p. 11.

84. Leonard Pitts Jr, 'Violence cloaked in Christianity', Virginian-Pilot \& Ledger Star, 9 April 2010, p. B-9.

85. 'Christian terrorists?', Christian Century, 4 May 2010, p. 7.

86. See Bilal A. Rana, 'Bomber, a fanatic,' Letters to the Editor, Detroit News, 14 May 2010, p. 12.

87. Rev. Rachel Hackenberg, 'Christian bows out of hate-filled take on faith', Sunday News (Lancaster, PA), 25 April 2010, p. 1.

88. J. C. Watts, 'Giving Christians a bad name', Las Vegas Review-Journal, 11 April 2010, p. 5D.

89. Vaughn Denton, 'Hutaree militia is not Christian', Letters to the Editor, Commercial Appeal (Memphis, TN), 7 April 2010, p. A11. 